\title{
Litter Dynamics in Eucalyptus and Native Forest in the Brazilian Cerrado
}

\author{
Fabiana Piontekowski Ribeiro ${ }^{1,2}$, Alcides Gatto ${ }^{1}$, Alexsandra Duarte Oliveira ${ }^{2}$, Karina Pulrolnik ${ }^{2}$, \\ Eloisa Aparecida Belleza Ferreira ${ }^{2}$, Arminda Moreira de Carvalho ${ }^{2}$, Ângela Pereira Bussinguer ${ }^{1}$, \\ Artur Gustavo Muller $^{2} \&$ Sebastiao Pires de Moraes Neto ${ }^{2}$ \\ ${ }^{1}$ Department of Forest Engineer, Brasília University, Brasília, Distrito Federal, Brazil \\ ${ }^{2}$ Brazilian Agricultural Research Corporation, Embrapa Cerrados, Planaltina, Distrito Federal, Brazil \\ Correspondence: Alexsandra Duarte de Oliveira, Brazilian Agricultural Research Corporation, Embrapa Cerrados, \\ BR 020, km 18, CP 08223, Brasília, Distrito Federal, CEP: 73310-970, Brazil. Tel: 55-61-3388-9809. E-mail: \\ alexsandra.duarte@embrapa.br
}

Received: July 8, 2018

Accepted: August 12, $2018 \quad$ Online Published: October 15, 2018

doi:10.5539/jas.v10n11p29

URL: https://doi.org/10.5539/jas.v10n11p29

\begin{abstract}
The aim of this study was to evaluate the litter dynamics in the seasons of the year in three areas: Forest formation Cerradão (CE), and in two hybrids stands of Eucalyptus urophylla $\times$ E. grandis with different ages: E1 (34-58 months) and E2 (58-82 months). The produced litter, stored litter and the remaining mass was collected over 720 days. The evaluation of the remaining litter mass in each area was performed from the random distribution of 648 litter bags on the soil. Chemical analyzes $(\mathrm{N}, \mathrm{P}, \mathrm{C})$ and the structural components of the cell wall (lignin, cellulose and hemicellulose) of the remaining litter were performed. The $\mathrm{C}$ of the litter stock was also determined. For both years of evaluation were observed higher biomass and $\mathrm{C}$ content in litter at E2. In contrast, the highest decomposition rate was for the $\mathrm{CE}$, especially in the second year of evaluation (mass remaining at 720 days of $35 \%$, $37 \%$ and $23 \%$ for E1, E2 and CE, respectively), attributed to the higher apparent liberation of $\mathrm{N}$, soil moisture and biodiversity in the native area. Lignin contents increased, cellulose decreased, and hemicellulose remained stable throughout the 720 days. It was also observed an increase in the $\mathrm{N}$ and $\mathrm{P}$ concentration of the remaining mass and positive correlations among the remaining mass and the $\mathrm{C}: \mathrm{N}$ and $\mathrm{C}: \mathrm{P}$ ratios. The $\mathrm{C}: \mathrm{N}$ ratio of litter was $\geq 76: 1$ at time 0 and $\geq 30: 1$ at 720 days for the three areas.
\end{abstract}

Keywords: cellulose, remaining mass, savanna

\section{Introduction}

Nutrient cycling in forest ecosystems is controlled primarily by climate, site, abiotic properties (topography, parent material), biotic communities and human activity (harvesting, fertilization) (Fonseca et al., 2018; Fujii et al., 2018; Osborne et al., 2017). In the context of sustainable production and environmental conservation, the maintenance of native forests and forest plantations is of great importance at local and global scale regulation of biogeochemical cycles (Atwell, Wuddivira, \& Wilson, 2018; León \& Osorio, 2014).

In terrestrial ecosystems, litterfall represents the first phase of vegetation-to-soil transference of carbon (C) and nutrient pools (Vitousek \& Sanford Jr., 1986). Thereafter, decomposition is an important process of nutrient return to the soil (Freschet et al., 2013; Hobbie, 2015). Nutrient availability and relations are widely considered decisive factors for litter decomposition, especially early stages of decay (Bachega et al., 2016; Prescott \& Gray, 2013).

Factors such as temperature and precipitation are extremely relevant for litter decomposition and incorporation into the soil-plant system (Santos, Carneiro, Martinez, \& Caldeira, 2017; Zhang et al., 2014), aside from C compounds such as lignin, cellulose and hemicellulose, which can act as regulators of soil nutrient fluxes (Brown \& Chang, 2014; Ferreira, Koricheva, Pozo, \& Graça, 2016; Swift, Heal, \& Anderson, 1979). Although climate greatly influences the biogeochemical cycles, it has been verified that, not only $\mathrm{C}$, but also the concentrations of nitrogen $(\mathrm{N})$ and phosphorus $(\mathrm{P})$ affect residue mineralization and have been used as quality parameters to explain decomposition rates in different systems, including forests plantations (Bachega et al., 2016; Prescott \& Gray, 2013). 
In recent decades' literature has pointed out patterns and mechanisms related to leaf litter dynamics, such as litter fall, standing stocks, decomposition, increases in $\mathrm{N}$ and refractory compounds with decomposition time (Berg, 2014; Ribeiro, Bussinguer, Hodecker, \& Gatto, 2017; Turner \& Lambert, 2016; Viera, Schumacher, \& Araújo, 2014). However, most of studies do not address jointly litterfall, litter layer and litter decomposition or litter dynamics assessments associated with changes in soil use. As it is also the main input of nutrients into the system, litter also contributes to C stocks, controls the fluxes of greenhouse gases (GHG) and defines ecosystems structural and functional patterns. Determination of net responses of ecosystems to environmental changes, therefore, requires monitoring of ecosystem processes under natural field conditions.

In keeping with the needs for developing science-based policy recommendations for climate change mitigation the collection of data in the different compartments includes: effects of land-use change on below and above-ground productivity and carbon/nutrients budgets of forests is fundamental to know the level of GHG emissions and its main sources (Intergovernmental Panel on Climate Change, 2007).

Since litter plays a critical role in the account for change in land use in order to fulfill the interactive research needs for the most accurate predictions we formulated the following hypothesis: in the Cerrado, quantity, quality and litter decomposition occurs due to environmental conditions, forest type (native $\times$ planted) and age of eucalyptus plantations.

To investigate the litter dynamics in these different conditions, the objectives of this study were: (1) to quantify litterfall and litter layer as a function of seasonality; (2) quantify the biomass and carbon stocks in the litter layer; (3) determine the decomposition rate and litter composition in terms of structural components (lignin, cellulose and hemicellulose) of the cell wall; and (4) to analyze the C, N and P concentrations of the remaining litter mass and their relationship with decomposition rates.

\section{Material and Methods}

\subsection{Study Site}

This study was carried out in the Cerrado of the Planalto Central, the central region of Brazil, at the rural center Quebrada dos Neres, Paranoá, Distrito Federal. The study areas consisted that correspond to the treatments: an area of native Cerrado (CE) vegetation (3.5 ha) and two Eucalyptus stands (12 and 19 ha) with the clones EAC 1528 (E1) and GG100 (E2), respectively, of the Eucalyptus urophylla $\times$ Eucalyptus grandis hybrid. The general characteristics of the study areas are listed in Table 1. 
Table 1. Description and history of the study areas in Paranoá, Distrito Federal, Brazil

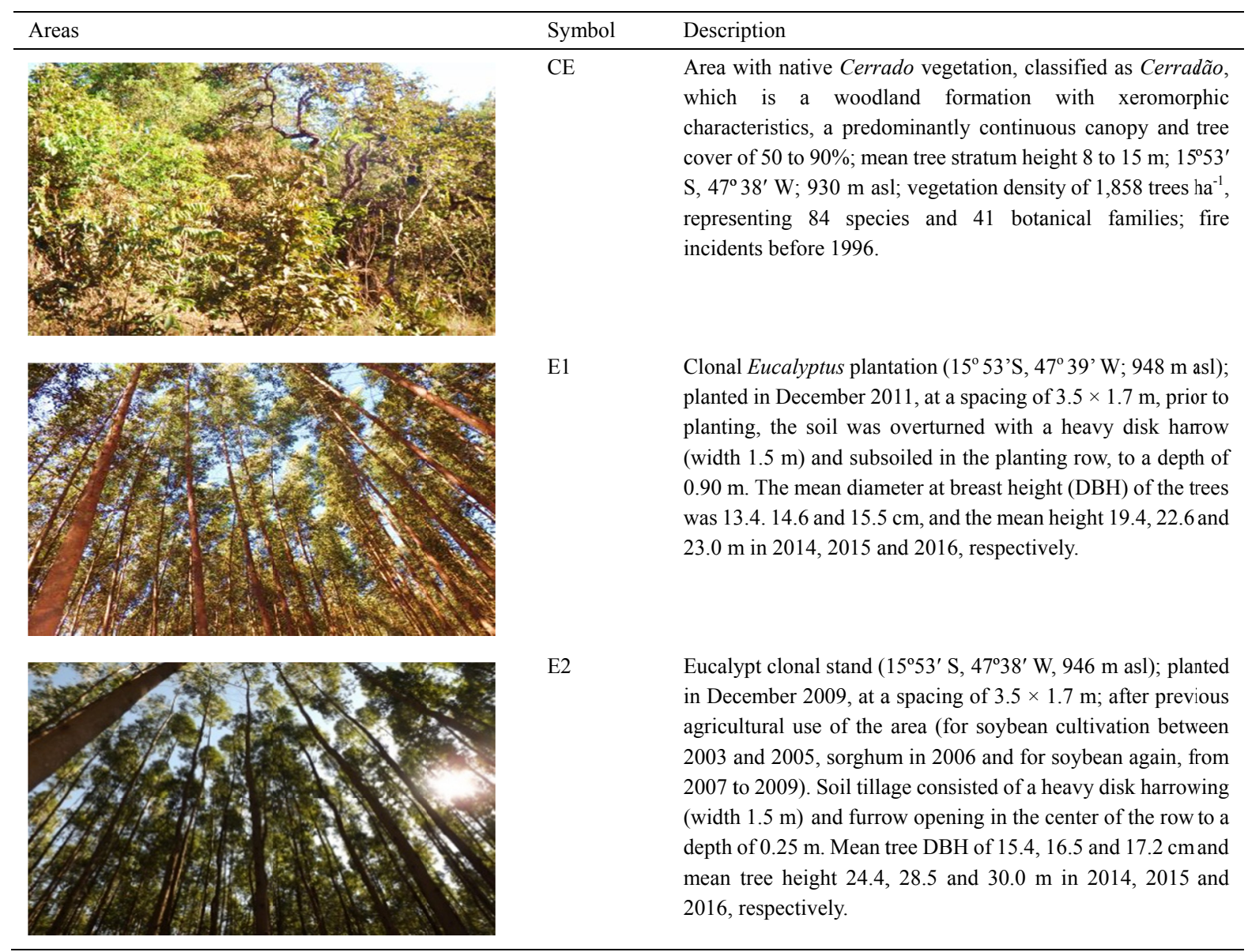

In the Eucalyptus plantations (E1 and E2), soil acidity was corrected by incorporating dolomitic limestone (2.5 $\left.\mathrm{Mg} \mathrm{ha}^{-1}\right)$ to a depth of $0.20 \mathrm{~m}$, and after two months, applying $700 \mathrm{~kg} \mathrm{ha}^{-1}$ of agricultural gypsum on the soil surface. Fertilization at planting consisted of $200 \mathrm{~g}$ per plant of NPK (5-25-15) fertilizer. After one year, a sidedressing of $60 \mathrm{~kg} \mathrm{ha}^{-1} \mathrm{~K}_{2} \mathrm{O}$ was applied in the form of potassium chloride, $50 \mathrm{~kg} \mathrm{ha}^{-1} \mathrm{~N}$ in the form of urea, and $1 \mathrm{~g}$ of B per plant in the form of borax. In January 2014, the $60 \mathrm{~kg} \mathrm{ha}^{-1} \mathrm{~K}_{2} \mathrm{O}$ application was repeated. The soils of the areas were classified as an Oxisol, a Latossolo Vermelho-Amarelo distrófico (Santos et al., 2013), with very clayey texture and clay content $\geq 60 \%$. The soil chemical properties $(0.00-0.05$ and $0.05-0.10 \mathrm{~m}$ layer) are shown in Table 2. 
Table 2. Soil chemical properties in the layers $(0.00-0.05$ and 0.05-0.10 m) in the three studied areas, two hybrids stands of Eucalyptus urophylla $\times$ E. grandis with different ages: E1 (34-58 months) and E2 (58-82 months', and forest formation Cerradão (CE), Distrito Federal, Brazil

\begin{tabular}{|c|c|c|c|c|c|c|}
\hline Property & E1 & $\mathbf{E 2}$ & $\mathbf{C E}$ & E1 & $\mathbf{E 2}$ & $\mathbf{C E}$ \\
\hline & \multicolumn{3}{|c|}{ 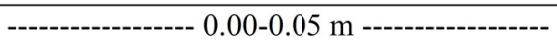 } & \multicolumn{3}{|c|}{ 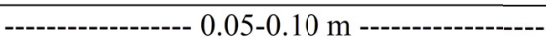 } \\
\hline $\mathrm{OM}\left(\operatorname{dag} \mathrm{kg}^{-1}\right)$ & 3.3 & 3.0 & 3.8 & 2.9 & 2.6 & 3.2 \\
\hline $\mathrm{pH}\left(\mathrm{H}_{2} \mathrm{O}\right)$ & 5.0 & 5.4 & 5.1 & 4.9 & 5.3 & 5.1 \\
\hline $\mathrm{P}\left(\mathrm{mg} \mathrm{dm}^{-3}\right)$ & 1.5 & 5.3 & 1.8 & 1.4 & 3.5 & 1.2 \\
\hline $\mathrm{H}+\mathrm{Al}\left(\mathrm{cmol}_{\mathrm{c}} \mathrm{dm}^{-3}\right)$ & 8.2 & 7.0 & 9.5 & 8.3 & 7.1 & 8.6 \\
\hline Sum of bases $\left(\mathrm{cmol}_{\mathrm{c}} \mathrm{dm}^{-3}\right)$ & 1.8 & 4.3 & 1.3 & 1.6 & 2.6 & 0.8 \\
\hline $\mathrm{CTC}\left(\mathrm{cmol}_{\mathrm{c}} \mathrm{dm}^{-3}\right)$ & 10.0 & 11.3 & 10.8 & 9.8 & 9.7 & 9.5 \\
\hline$V(\%)$ & 17.7 & 38.0 & 11.8 & 15.8 & 26.7 & 8.7 \\
\hline $\mathrm{B}\left(\mathrm{mg} \mathrm{dm}^{-3}\right)$ & 0.5 & 1.1 & 0.5 & 0.5 & 0.9 & 0.5 \\
\hline $\mathrm{Zn}\left(\mathrm{mg} \mathrm{dm}^{-3}\right)$ & 0.3 & 0.6 & 0.6 & 0.3 & 1.3 & 0.4 \\
\hline
\end{tabular}

Note. Soil chemical as described by Claessen (1997). OM: organic matter, Walkey-Black method; $\mathrm{pH}$ in water, 1:2.5 soil:solution relation; $\mathrm{H}+\mathrm{Al}$ : potential acidity, extractor calcium acetate $0.5 \mathrm{~mol} \mathrm{~L}^{-1} \mathrm{pH} 7$; CEC: cation exchange capacity; B: hot water extractor; Zn: extractor Mehlich ${ }^{-1}$.

According to the Köppen classification system, the regional climate is Aw, with two well-defined climatic seasons: dry, between May and September, and rainy, between October and April. During the study period, the mean temperature was $21.6{ }^{\circ} \mathrm{C}$ and total annual rainfall $1,199.9 \mathrm{~mm}$, according to the database of the Climatological Station of the Technical Assistance and Rural Extension Company of the Federal District (Emater-DF).

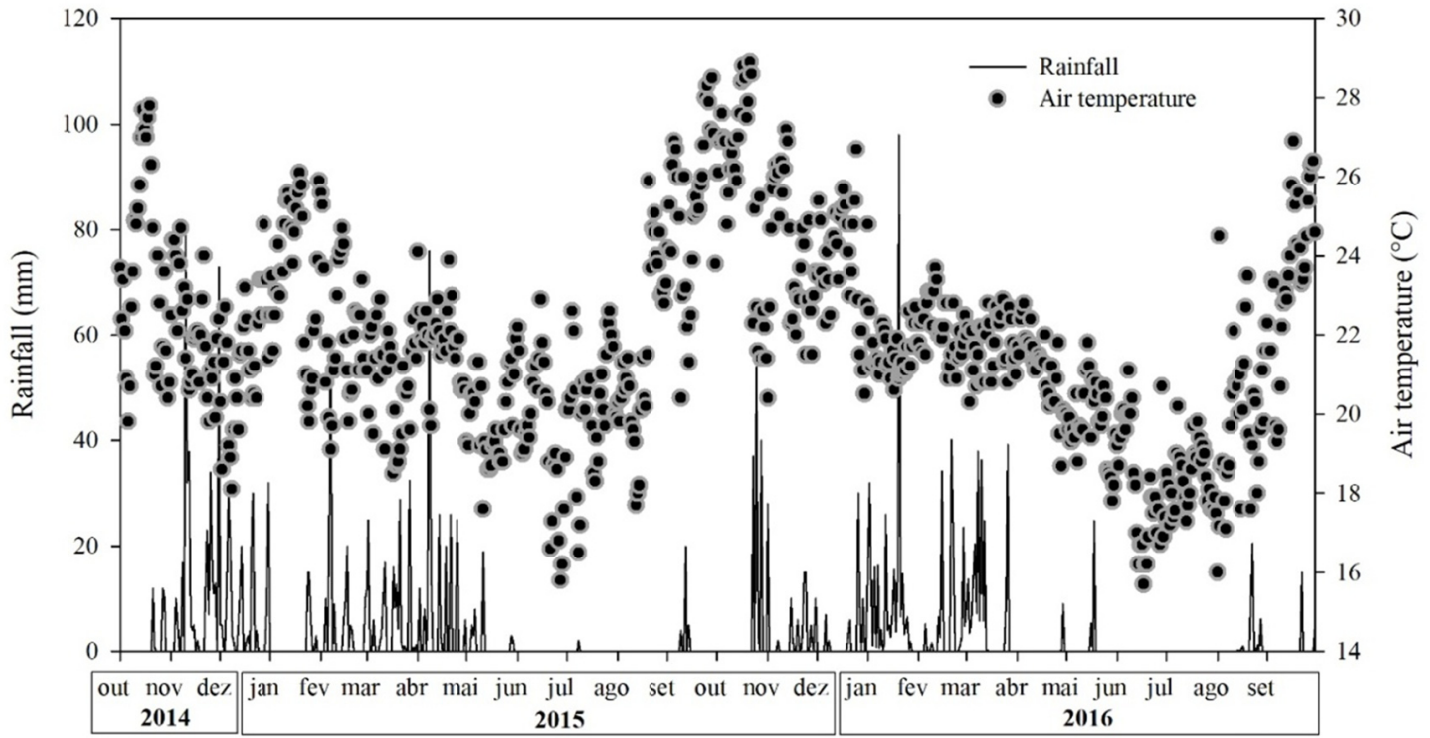

Figure 1. Rainfall $(\mathrm{mm})$ and air temperature $\left({ }^{\circ} \mathrm{C}\right)$ from October 2014 to September 2016, Paranoá, Distrito Federal, Brazil

\subsection{Litter Analysis}

To estimate litterfall between October 2014 and September 2016, 24 litter collectors of $0.25 \mathrm{~m}^{2}$ were randomly placed in each of the three studied areas, fixed to a framework $0.50 \mathrm{~m}$ above the soil surface, for monthly collections. To quantify the amount of forest litter deposited on the soil (Litter layer), nine random samples were taken, in two samplings per season (dry and rainy season), using a metallic $0.25 \mathrm{~m}^{2}$ frame, laid loosely on the forest floor at a distance of at least $5 \mathrm{~m}$ between the evaluated points.

The samples of litterfall were analyzed for seasonality, considering the dry and rainy seasons. The annual yields of litterfall and litter layer per area (dry mass) were calculated by the following equations: 


$$
\begin{gathered}
\mathrm{L}=\left(\Sigma \mathrm{Y} \times 10^{4}\right) / \mathrm{As} / 10^{3} \\
\mathrm{Ll}=\left(\mathrm{Z} \times 10^{4}\right) / \mathrm{As} / 10^{6}
\end{gathered}
$$

where, $\mathrm{L}=$ litter yield $\left(\mathrm{kg} \mathrm{ha}^{-1} \mathrm{yr}^{-1}\right) ; \mathrm{Y}=$ monthly litterfall $\left(\mathrm{g} \mathrm{m}^{-2}\right.$ month $\left.^{-1}\right) ; \mathrm{As}=$ sampling area $\left(0.25 \mathrm{~m}^{2}\right) ; \mathrm{Ll}=$ litter layer $\left(\mathrm{Mg} \mathrm{ha}^{-1} \mathrm{yr}^{-1}\right) ; \mathrm{Z}=$ litter layer per season $\left(\mathrm{g} \mathrm{m}^{-2}\right)$.

For the evaluation of the remaining litter mass per area, 648 litter bags $(0.20 \times 0.30 \mathrm{~m}$, made of $2 \mathrm{~mm}$ nylon mesh) were randomly distributed on the forest floor. The initial weight per litter per bag was $20 \mathrm{~g}$ of dry material (adapted from Santos and Whitford, 1981). From October 2014 to September 2016, every three months 27 litter bags were collected and analyzed.

The litter was packed in labeled paper bags, sealed and sent to the laboratory to determine the fresh weight. Thereafter, the material was dried to constant weight in a forced air circulation oven (at $65^{\circ} \mathrm{C}$ for $72 \mathrm{~h}$ ) and then weighed again to determine dry weight.

The sequential method adapted from Robertson and Van Soest (1981) was used to analyze the structural composition of the cell wall of the remaining mass in the litter bags. The ground material was analyzed for neutral detergent fiber (NDF), acid detergent fiber (ADF) and crude lignin (L). The hemicellulose and cellulose contents were calculated, respectively, as the difference between them (NDF minus ADF) and (ADF minus L).

Of the remaining mass and litter layer $1.0 \mathrm{~g}$ litter samples were ground in a mortar and sieved $(0.2 \mathrm{~mm})$, and subsequently the total $\mathrm{C}$ content was determined using a Vario MACRO cube Elementary analyzer (Elementar Analyzer system, Hanau, Germany). The total C content was multiplied by the litter layer to obtain the C stock. The total $\mathrm{N}$ concentration was determined by the Kjeldahl method, after sulfur digestion, and $\mathrm{P}$ was determined by molecular absorption spectrophotometry (Empresa Brasileira de Pesquisa Agropecuária, 2009).

\subsection{Determination of Soil Moisture}

One composite sample which is made up of eight sub samples of equal volume was taken at each plot $(0.00-0.10$ $\mathrm{m}$ layer). From each composite sample, a soil aliquot was removed to measure soil moisture content. The moisture content (gravimetric method) was calculated as the difference among dry and fresh weight, according to the following equation:

$$
\mathrm{m}=(\mathrm{Wf}-\mathrm{Wd}) / \mathrm{Wd}
$$

where, $\mathrm{Wf}=$ fresh weight $(\mathrm{g})$ and $\mathrm{Wd}=$ dry weight $(\mathrm{g})$, and moisture $\mathrm{m}-$ moisture $(\mathrm{g} / \mathrm{g})$ expressed as percent (Claessen, 1997).

\subsection{Data Processing and Analysis}

The quantitative litter variables (litterfall, litter layer and litter decomposition) and qualitative variables (lignin, cellulose, hemicellulose, $\mathrm{C}: \mathrm{N}$ and $\mathrm{C}: \mathrm{P}$ ) were tested for normality (Shapiro-Wilk), followed by analysis of variance (ANOVA). Subsequently, the means were compared by the Tukey test $(p<0.05)$ by software SISVAR version 5.6, to detect possible differences among the areas, with regard to seasonality and over time in each area. Carbon was compared between treatments and between the years. All figures were generated on the SigmaPlot.

The data of remaining litter mass and qualitative variables were compared among the areas for the sampling periods $(0,90,180,270,360,450,540,630$, and 720 days), and analyzed for each area over time by regression analysis.

Litter decomposition per area was calculated as proposed by Santos and Whitford (1981), based on the decomposition percentage, where the remaining litter rate was determined as the difference between the initial total litter mass amount (100\%) and each rate per assessment period. In addition, models with one, two, three and four parameters were tested and the one that best fit the data was the exponential model of one parameter proposed by Olson (1963) was used to calculate the mass (k) decomposition:

$$
\mathrm{y}=\mathrm{A} \cdot \mathrm{e}^{-\mathrm{kt}}
$$

where, $y$ is the amount of remaining material after a period of time; A the weight of the material at time zero $(t=$ 0 ); $\mathrm{k}$ the decomposition constant obtained by software Sigma Plot for Windows 12.5 based on the litter quantities in the bags; and the time in days (720 d).

The decomposition constant $(\mathrm{k})$ allows to calculate the time projection required for the disappearance of $95 \%(\mathrm{t}$ $=3 / \mathrm{k})$ and $99 \%(\mathrm{t}=3 / \mathrm{k})($ Olson, 1963). The remaining mass data together with the quantitative variables (lignin, cellulose, hemicellulose, and C:N and C:P ratio) were subjected to Pearson's statistical correlation analysis, 
followed by Student's t-test, using the free software R (version 3.2.2). The liberation apparent rate for $\mathrm{N}$ and $\mathrm{P}$ content was calculated by the difference of those nutrients between times 0 and 720 days $\left[\left(\mathrm{X}_{0}-\mathrm{X}_{720}\right) \times 100\right]$.

\section{Results}

\subsection{Litterfall and Litter Layer}

The evaluations between October 2014 and September 2016 showed differences in litterfall owing to seasonality in the areas E1 $(\mathrm{p}<0.01)$ and CE $(\mathrm{p}=0.01)$ in the dry season of 2015 (Table 3$)$. Among the areas, there were no statistical differences in litterfall, except in the dry season of 2016, with higher litterfall in the CE area $(p<0.01)$. Moreover, there were seasonal differences in the two study years, with an about 60 and $45 \%$ higher litterfall in the dry seasons of 2015 and 2016 than in the rainy seasons (2014/15 and 2015/16), only in the E1 area, the total litterfall was higher in the second than in the first year (Table $3 ; \mathrm{p}=0.02)$.

Table 3. Means and standard deviation of litterfall per season (rainy and dry) and per year in Eucalyptus stands E1 (planted in 2011, clone EAC 1528) and E2 (planted in 2009, clone GG100) and CE (native cerrado vegetation), Distrito Federal, Brazil

\begin{tabular}{|c|c|c|c|c|c|c|}
\hline \multirow[b]{2}{*}{ Areas } & \multicolumn{4}{|c|}{ Season } & \multicolumn{2}{|c|}{ Total } \\
\hline & $\begin{array}{c}\text { Rainy } \\
(2014-2015)\end{array}$ & $\begin{array}{c}\text { Dry } \\
(2015)\end{array}$ & $\begin{array}{c}\text { Rainy } \\
(2015-2016)\end{array}$ & $\begin{array}{c}\text { Dry } \\
(2016)\end{array}$ & $\begin{array}{c}\text { Year 1 } \\
(2014-2015)\end{array}$ & $\begin{array}{c}\text { Year } 2 \\
(2015-2016)\end{array}$ \\
\hline & ------------------' & --------- k & $\mathrm{ha}^{-1}$----------- & ------------------- & --------------- & $a^{-1}-----\cdot-\cdot-\cdot-\cdot$ \\
\hline E1 & $(415 \pm 105) \mathrm{aB}$ & $(584 \pm 184) \mathrm{aA}$ & $(270 \pm 121) a B$ & $(324 \pm 118) b B$ & $(6048 \pm 234) \mathrm{aA}$ & $(3579 \pm 104) b B$ \\
\hline E2 & $(441 \pm 122) \mathrm{aA}$ & $(507 \pm 137) \mathrm{aA}$ & $(405 \pm 106) \mathrm{aA}$ & $(384 \pm 98) \mathrm{bA}$ & $(5582 \pm 209) \mathrm{abA}$ & $(4845 \pm 107) \mathrm{aA}$ \\
\hline $\mathrm{CE}$ & $(314 \pm 98) \mathrm{aBC}$ & $(525 \pm 156) \mathrm{aA}$ & $(223 \pm 138) \mathrm{aC}$ & $(495 \pm 171) \mathrm{aB}$ & $(4076 \pm 277) \mathrm{bA}$ & $(4658 \pm 281) \mathrm{abA}$ \\
\hline
\end{tabular}

Note. Rainy season (October to April) and Dry season (May to September); Seasonal data = average yield per season; Total $=$ sum of 12 yield months. Year-1 (October 2014 to September 2015) and Year-2 (October 2015 to September 2016). Different lowercase letters in a column differ between areas, different uppercase letters in a row differ between seasons (dry and rainy) and per year (Tukey, $\mathrm{p}<0.05$ ).

Regarding to the litter layer, for both years, the greatest stock of biomass in the forest litter was observed in the E2 (15 and $\left.16 \mathrm{Mg} \mathrm{ha}^{-1}\right)$, followed by E1 (12 and $\left.14 \mathrm{Mg} \mathrm{ha}^{-1}\right)$ and CE (7 and $\left.8 \mathrm{Mg} \mathrm{ha}^{-1}\right)$, respectively (Figure 2). The stored $\mathrm{C}$ in this litter in the first year (October 2014 to September 2015) was 5.6 $\mathrm{Mg} \mathrm{ha}^{-1}, 7.2 \mathrm{Mg} \mathrm{ha}^{-1}, 3.6$ $\mathrm{Mg} \mathrm{ha}^{-1}$, and in the second year (October 2015 to September 2016) was $7.2 \mathrm{Mg} \mathrm{ha}^{-1}, 7.8 \mathrm{Mg} \mathrm{ha}^{-1}$ and $4.3 \mathrm{Mg} \mathrm{ha}^{-1}$ for the E1, E2 and CE areas, respectively (Figure 2). In the second year, the increase in biomass and $\mathrm{C}$ concentration, caused the increase of the litter $\mathrm{C}$ stock in E1 area $(\mathrm{p}<0.01)$.

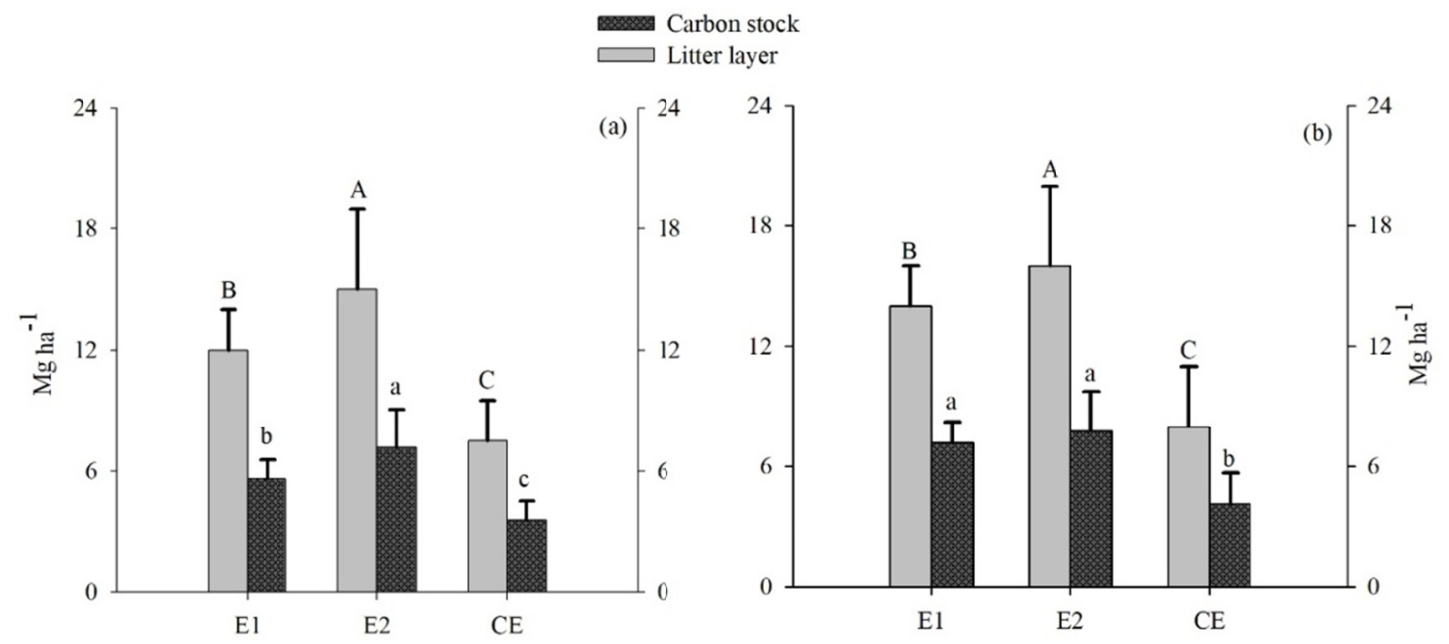

Figure 2. Litter layer and carbon stock year-1 (October 2014 to September 2015) (a) and year-2 (October 2015 to September 2016) (b) in Eucalyptus stands E1 (planted in 2011, clone EAC 1528) and E2 (planted in 2009, clone GG100) and CE (native cerrado vegetation), Distrito Federal, Brazil 
Note. Bars indicate standard deviations; Capital letter represent differences among litter layer and lowercase letters difference between carbon stock $(\mathrm{p}<0.05)$.

\subsection{Litter Decomposition}

The litter decomposition constant $(\mathrm{k})$ was 0.0013 for E1 and E2, and 0.0021 for the CE. The time required to reach $95 \%$ mass loss ranged from 6.4 years in the E1 and E2 areas to 4 years in the CE, respectively, but length of time to reach $99 \%$ mass loss would be 4.1 and 2.6 extra years for Eucalyptus areas and CE. The three areas had adjustment with the linear model $\mathrm{R}^{2} \geq 0.97(\mathrm{p}<0.01)$. Litter decomposition was similar in the three areas until the $360^{\text {th }}$ evaluation day. Thereafter, the loss of litter mass increased in the CE area, while no significant differences were observed in E1 and E2 (Figure 3a). The remaining litter mass in the areas was 54, 51, and 54\% on the $360^{\text {th }}$ day and 35,37 and $22 \%$ on the $720^{\text {th }}$ day for E1, E2 and CE, respectively (Figure 3a).

In the three areas, litter decomposition was positively correlated $(r \geq 0.80, p=0.05)$ with soil moisture. Therefore, litter mass loss was also correlated with soil moisture that was higher in the CE area (20 to 35\%; $\mathrm{p}=$ 0.008 ), and ranged from 15 to $21 \%$ in the areas E1 and E2 (Figure $3 \mathrm{~b}$ ) over the two-year assessment.

Litter mass loss at the end of the first and second year was 1.5, 1.6 and 1.5, and 2.2, 2.1 and 2.6 Mg ha ${ }^{-1}$ for the E1, $\mathrm{E} 2$ and CE areas, respectively. This represents, on average, that the decomposition in the E1, E2 and CE areas was $7.9,6.6$ and $16.8 \%$ in relation to the litter layer stored above the ground.
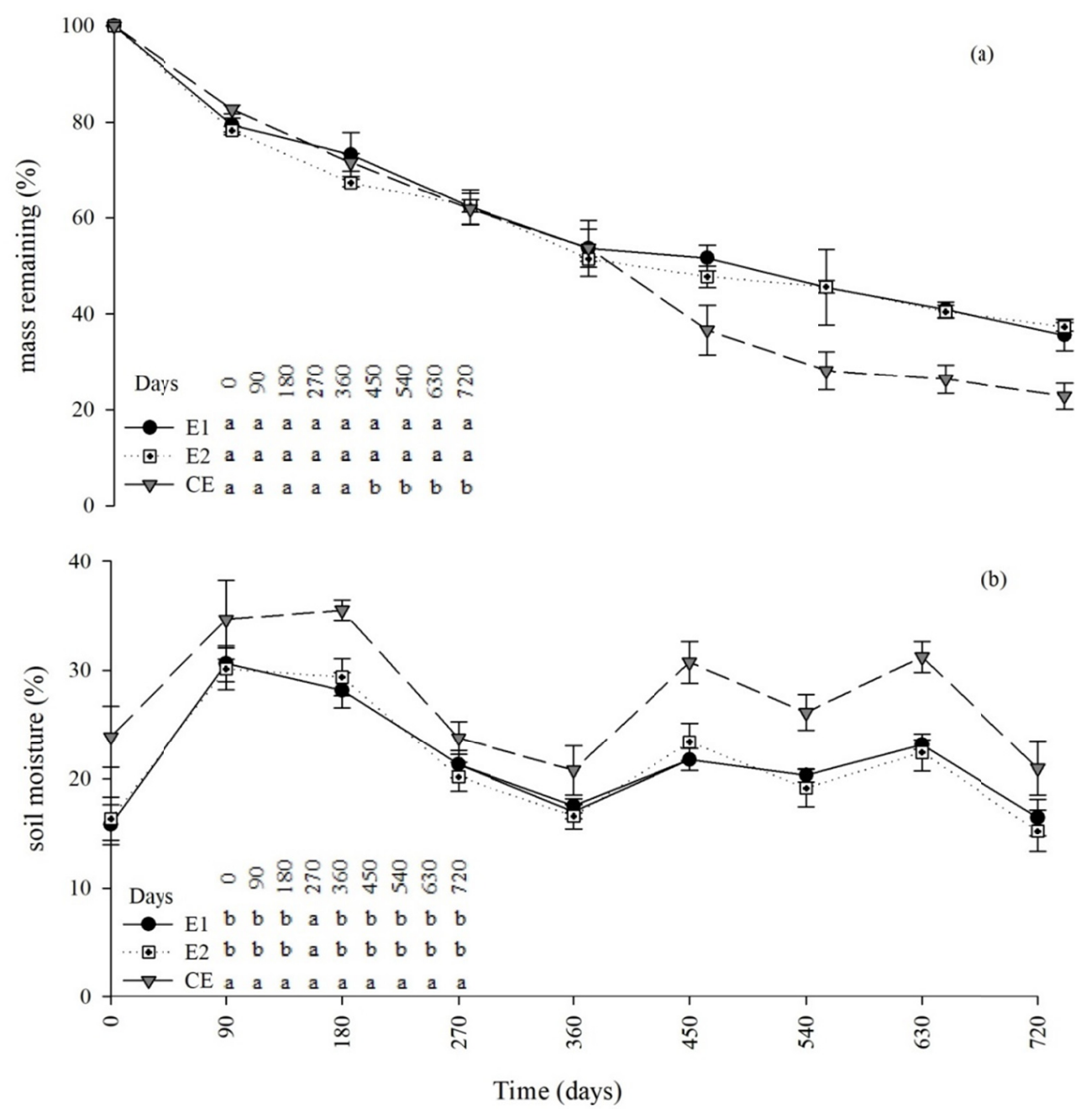

Figure 3. Exponential curve and percentage of remaining litter mass (a) and soil moisture (b) over 720 days in Eucalyptus stands E1 (planted in 2011, clone EAC 1528) and E2 (planted in 2009, clone GG100) and CE (native cerrado vegetation), Distrito Federal, Brazil 
Note. Bars indicate standard deviations for each sampling day $(\mathrm{n}=9)$ after time 0 . Different letters indicate significant differences between areas for each sampling day after time $0(\mathrm{p}<0.05)$.

\subsection{Lignin, Cellulose and Hemicellulose Contents}

Throughout the 720 days of litter decomposition, the lignin contents were higher in CE on most days of the evaluation period $(\mathrm{p}<0.05)$ (Figure $4 \mathrm{a})$. In the same period, the lignin content increased from 11 to $17 \%$ in E1, from 11 to $18 \%$ in $\mathrm{E} 2$ and from 14 to $29 \%$ in CE.

Contrary to lignin, the cellulose contents decreased by $3 \%, 5 \%$ and $4 \%$ in the areas E1, E2 and CE, respectively (Figure 4b). For the hemicellulose contents, statistical differences between the study areas were observed after 360,450 and 540 days, with higher values in E2 than CE $(\mathrm{p}<0.05)$. Throughout the evaluation period, the hemicellulose contents, unlike the other components, were constant (Figure 4c).

Correlations of -0.79 and -0.93 were observed between the lignin and remaining mass contents for E1 and E2, respectively, whereas for remaining mass and cellulose content, the correlations were $>0.75$ in the studied areas.
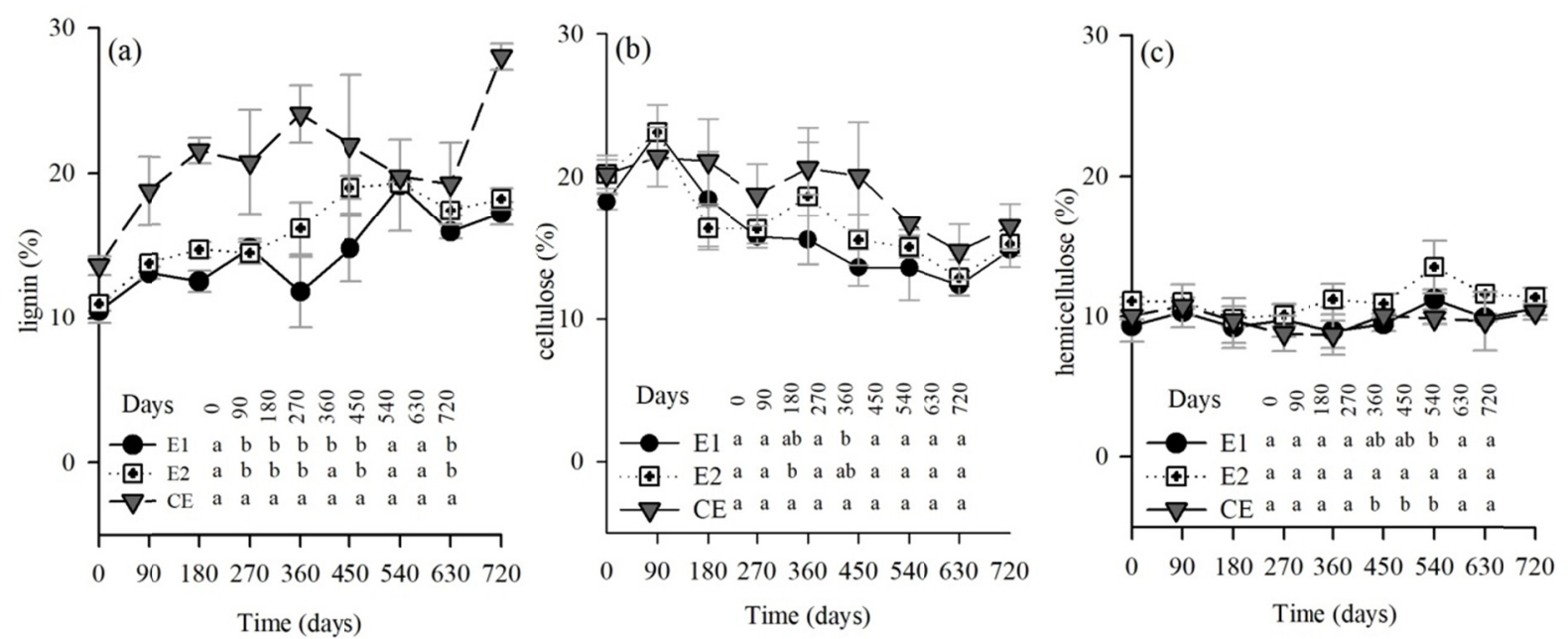

Figure 4. Percentage of lignin (a), cellulose (b) and hemicellulose (c) of the remaining litter mass over a period of 720 days in Eucalyptus stands E1 (planted in 2011, clone EAC 1528) and E2 (planted in 2009, clone GG100) and CE (native cerrado vegetation), Distrito Federal, Brazil

Note. Bars indicate the standard deviations for each sampling day $(n=9)$ after time 0 . Different letters indicate significant differences between areas for each sampling day after time $0(\mathrm{p}<0.05)$.

\subsection{C, N and P Concentrations}

A decreasing trend of the $\mathrm{C}$ concentration in the remaining litter mass was observed during the evaluation period. At the first sampling, the $C$ concentrations were $530.5,532.8$ and $539.6 \mathrm{~g} \mathrm{~kg}^{-1}$ and at the last, 474.8, 449.7 and $409.3 \mathrm{~g} \mathrm{~kg}^{-1}$ for E1, E2 and CE, respectively (Figure 5a).

The $\mathrm{N}$ litter concentrations indicated an increase over time of decomposition, due to the mass loss in all evaluated areas. The $\mathrm{N}$ concentrations were statistically different at 450 days (Figure $5 \mathrm{~b} ; \mathrm{p}=0.01$ ) and at 630 days (Figure $5 \mathrm{~b} ; \mathrm{p}=0.01$ ). During 720 days the apparent liberation rate for $\mathrm{N}$ was 36,33 , and $52 \%$ in the E1, E2 and $\mathrm{CE}$ areas, respectively.

The remaining $P$ was highest in E2 $(p<0.007)$, except at time zero, compared to the other areas throughout the entire sampling period (Figure 5c). Although there was an increase in $\mathrm{P}$ concentration with increasing decomposition time of litter in the field, especially in area E2, which was higher in relation to the other areas. The apparent liberation rate for this element was 54,38 , and $61 \%$ in the E1, E2 and CE areas, respectively. 

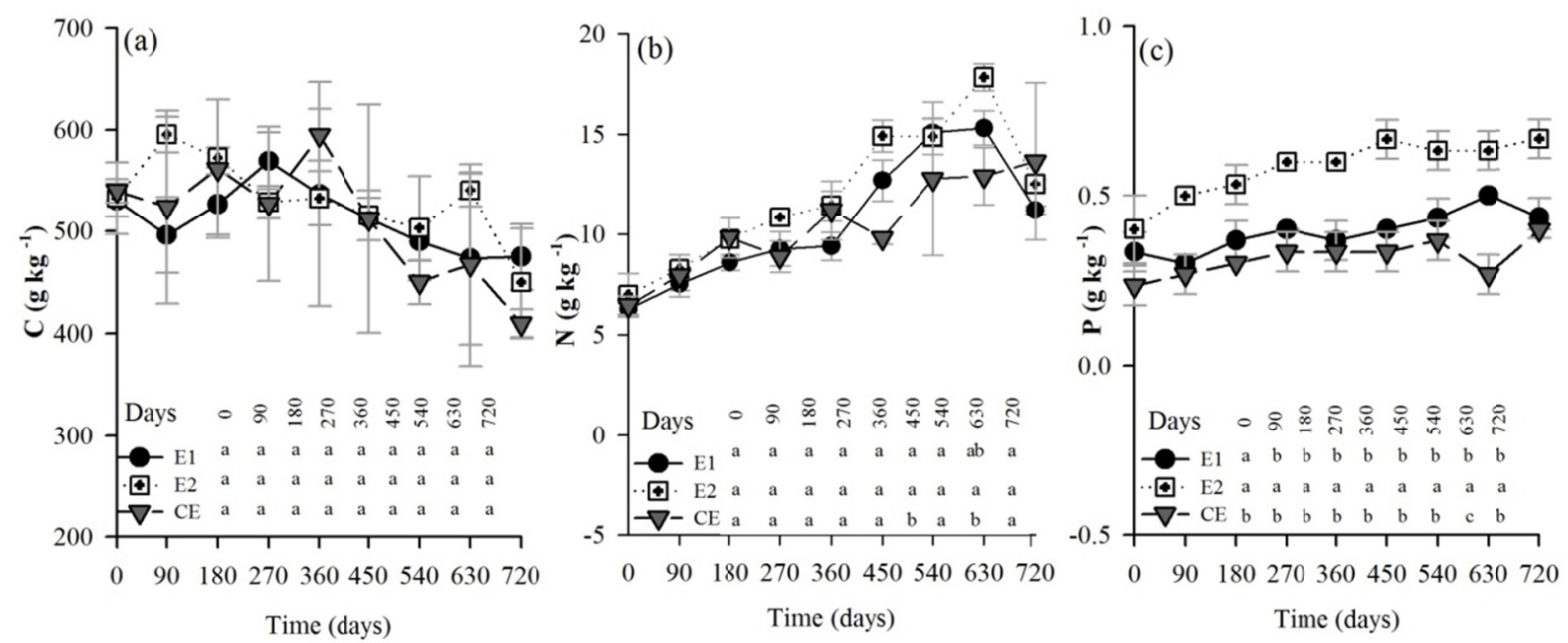

Figure 5. Concentrations of carbon $(\mathrm{C})(\mathrm{a})$, nitrogen $(\mathrm{N})(\mathrm{b})$ and phosphorus $(\mathrm{P})(\mathrm{c})$ of the remaining litter mass during 720 days in Eucalyptus stands E1 (planted in 2011, clone EAC 1528) and E2 (planted in 2009, clone GG100) and CE (native cerrado vegetation), Distrito Federal, Brazil

Note. Bars indicate the standard deviations for each sampling day $(n=9)$ after time 0 . Different letters indicate significant differences between areas for each day of sampling after time $0(p<0.005)$.

The C:N ratio tended to decrease in the evaluation period ( 720 days). In the initial phase (time 0$)$ this ratio was $\mathrm{C}: \mathrm{N}>76: 1$ and at the end of the evaluation period $\mathrm{C}: \mathrm{N}>30: 1$. In the evaluations $(n=9)$, no significant differences were observed for the $\mathrm{C}: \mathrm{N}$ ratio among the areas (Figure 6a), but differences in the $\mathrm{C}: \mathrm{N}$ ratio at time 0 and after 720 days were significant E1 $(\mathrm{p}<0.01)$, E2 $(\mathrm{p}<0.01)$ and CE $(\mathrm{p}<0.001)$.

The C:P ratio also showed a decreasing pattern over time and was lowest for $\mathrm{E} 2$ at most sampling times (Figure $6 \mathrm{~b})$. The correlations between remaining mass and $\mathrm{C}: \mathrm{N}(\mathrm{r}>0.92, \mathrm{p}=0.05)$ and $\mathrm{C}: \mathrm{P}(\mathrm{r}>0.85, \mathrm{p}=0.005)$ were positive and significant for all areas studied.

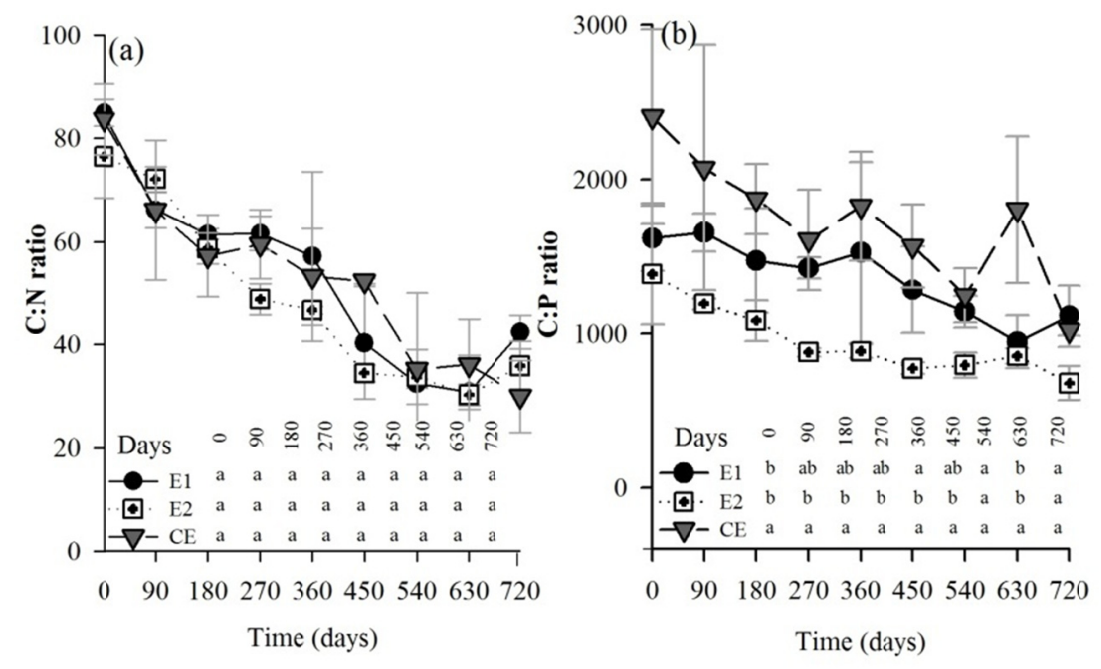

Figure 6. Pattern of the C:N (a) and C:P (b) of the remaining litter mass over 720 days in Eucalyptus stands E1 (planted in 2011, clone EAC 1528) and E2 (planted in 2009, clone GG100) and CE (native cerrado vegetation), Distrito Federal, Brazil

Note. Bars indicate the standard deviations for each sampling day $(n=9)$ after time 0 . Different letters indicate significant differences between areas for each sampling day after time $0(p<0.05)$. 


\section{Discussion}

\subsection{Litterfall and Litter Layer Dynamics}

The litter on the forest floor indicates a seasonal effect on litterfall (Table 3), since the native vegetation is adapted to the extreme rainfall seasonality of the Cerrado, by reducing plant transpiration during the dry season and by the presence of drought deciduous species that eventually shed their leaves. Several studies corroborate this finding (Giácomo, Pereira, \& Machado, 2012; Oliveira, Marimon-Junior, Mews, Valadão, \& Marimon, 2017; Souza et al., 2016) and also explain the greater input of litterfall and litter layer biomass in the dry season.

The largest litter layer in the E2 area, independent of the year, is due to the trees stand of E2 being older, with a denser canopy, resulting in more dropping of branches (natural pruning). After canopy closure, the leaves on branches at the canopy base are shaded, reducing the sunlight interception and intensifying natural pruning (Paiva \& Leite, 2015).

In this trial, the litterfall in the Eucalyptus stands was lower than reported by other authors who studied different species of Eucalyptus (Schumacher, Corrêa, Viera, \& Araújo, 2013; Viera et al., 2014). The litter layer, in turn, was higher (13.5 to $15 \mathrm{Mg} \mathrm{ha}^{-1} \mathrm{yr}^{-1}$ ) than found in other studies regarding Eucalyptus forests in Brazil (Barbosa, Barreto-Garcia, Gama-Rodrigues, \& Paula, 2017; Gatto et al., 2014; Ribeiro et al., 2017; Santos et al., 2017; Souza et al., 2016).

In the case of planted forest systems, changes in litterfall and litter layer can be influenced by characteristics of the species, particularly of the chemical composition (Ferreira et al., 2016), management, plant density (Hakamada, Hubbard, Ferraz, Stape, \& Lemos, 2017), age of trees (Corrêa, Schumacher, \& Momolli, 2016), type of clone (Conti-Junior, Silva, \& Couto, 2017) and climatic conditions (temperature and precipitation) (Binkley et al., 2017; Carvalho et al., 2017).

The litterfall do not always reflect the litter layer in the forest floor (Table 3 and Figure 2), notably in the E1 area, where greatest amount of litterfall in the first year, did not result in highest litter layer in the same year. The dynamics of the litter layer depends not only on the litterfall amount, but also on the combination of factors such as, decomposition rate, nutrient availability and forest age, that are decisive in the biogeochemical cycles and ecosystem structure (Guendehou et al., 2014; Pinto et al., 2016; Schumacher et al., 2013).

The $\mathrm{C}$ stock in the litter layer indicate increase during the studied period. Although the E2 presented larger $\mathrm{C}$ stocks in the litter layer, it was in the $\mathrm{E} 1$ that a higher rate of increase of $\mathrm{C}$ was observed from year to year (Figure 2). This behavior might have been affected by the forest growth stages of E1. Wink et al. (2013) report that eucalyptus stands presented a significant variation of litter stock and $\mathrm{C}$ stock. The litter deposition and nutrient cycling in forest ecosystems are the main route of entry of $\mathrm{C}$ in the soil-plant system and increase rapidly with plantation age (Du et al., 2015).

In the Cerrado, litterfall and litter layer did differ between the Eucalyptus forest systems with different ages and clones. Seasonality influenced mainly the native vegetation, with higher biomass (litterfall) on the soil in the dry season, while in the rainy season, a higher mass loss was observed in all studied areas. Biomass and litter carbon can be influenced by age in the case of eucalyptus stands.

\subsection{Litter Decomposition Process}

The litter decomposition rates are considered fast if there is small amounts of accumulation in the soil surface, a condition not found in the present study. For Olson (1963), this condition is reached when the values of $\mathrm{k}$ are between 1.0 and 4.0. The constants $\mathrm{k}$ found in this study were smaller than 1.0, indicating that all areas present a slow rate of decomposition.

The rapid decomposition within up to 90 days (Figure 3a) probably is results from the fragmentation of litter into smaller particles by physical agents, soil biota and the release of more soluble compounds such as sugars, starches and proteins, which are rapidly consumed by decomposing organisms (Swift et al., 1979; Oliveira et al., 2016). After this period, most of the more resistant or recalcitrant structures, rich in lignin, as well as in leaf veins and petioles, remain, decreasing the decomposition rate over time (Baumann et al., 2009; Hammel, 1997).

The highest litter mass loss in the CE area can be explained by water availability and biodiversity. A greater diversity of native vegetation species, provides a better environment and food supply for leaf-cutting ants (Silva \& Vasconcelos, 2011), which leads to greater fragmentation of plant material, speeding up physical breakdown and biochemical transformation of organic material (Oliveira et al., 2017). Moreover, to keep leaf cutting ants population below the economic injury level, Brazilian Eucalyptus forest producers provide broadcast application of pesticides for long-term pest, especially during the first three years of plant age (Zanetti et al., 2014). 
Another important finding in this study is the fact that native vegetation provided the highest water retention in the soil what might reflect in the litter moisture. Thus, higher soil moisture, favors maintenance of environmental conditions for preservation of litter food web (Nouvellon et al., 2012). Biological diversity of macro and meso fauna, microorganisms, as well as better microbiological properties, can be used as indicators of more fast decomposition (Oliveira et al., 2016). Castro, Silva, Quirino, Bustamante, \& Kruger (2016) also report that the abundance of soil microbial communities is profoundly affected by the considerable seasonal variation in water availability, which is characteristic of the Cerrado biome.

The decomposition of the total biomass and the cycling of most nutrients through litterfall and decomposition were at least twice higher than in the Cerrado sensu stricto. Thus, it is likely that the rapid and effective cycling of nutrients observed in the cerradão might be a key condition guaranteeing the ability of the cerradão to colonize new areas previously occupied by the typical Cerrado (Oliveira el al., 2017).

The greatest biomass stock in the litter layer of Eucalyptus stands resulted from the higher deposition and low decomposition of the plant material. In general, the genus Eucalyptus sp. has slow rates of litter decomposition, of generally less than $50 \%$ within 12 months, independent of the management and soil-climate conditions (Bachega et al., 2016; Souza et al., 2016). Other studies report a higher decomposition rate in relation to our findings, with a decomposition constant varying from 0.0015 to 0.56 (Cizungu et al., 2014; Pinto et al., 2016; Schumacher et al., 2013; Viera et al., 2014).

The chemical composition of eucalypt leaves might decrease the microbial colonization, by the presence of essential oils and other allelopathic chemical compounds that hinder the establishment and action of microorganisms, preventing colonization and subsequent decomposition and mineralization (Ferreira et al., 2016; He et al., 2014).

The litter decomposition is higher in the area of natural Cerrado vegetation, where soil moisture is more adequate. The lignin and cellulose contents function as indicators of litter decomposition in Eucalyptus and native plantations. The 720 days of evaluation were not enough to liberation the lignin and hemicellulose contents in any of the studied areas.

\subsection{Components of the Remaining Litter}

The increase in lignin content in the remaining litter mass after 720 days of evaluation in all three areas (Figure 4a) can be explained by the initial loss of more easily decomposed carbohydrates from the plant material. In addition, the decomposition rates are initially determined by rapidly proliferation bacteria, while in later stages, the rates are determined mostly by fungi (Swift et al., 1979). This behavior is a result of the increase in the proportion of more recalcitrant materials such as lignin (Baumann et al., 2009) throughout the decomposition process.

This organic fraction is described as the most resistant to degradation, which results in increasing concentration throughout the decomposition process, due to the release of the most soluble C forms initially (Hammel, 1997). It is worth mentioning that decomposition is a dynamic process, driven by a rapid succession of organism communities conditioned by the substrate quality and environmental conditions (Oliveira et al., 2016; 2017).

Litter decomposition was positively correlated with the reduction in contents of cellulose, the least recalcitrant of the analyzed C compounds. Although hemicellulose is the most labile structural component (Wagner \& Wolf, 1999), cellulose was broken down more rapidly. There are indications that the release rate of hemicellulose is proportional to loss of mass, and the fact that its release is constant over time causes the hemicellulose not to be affected by the litter decomposition stage in two years of evaluation.

The $\mathrm{N}$ and $\mathrm{P}$ concentrations increased in the 720 days of evaluation, when the mass loss was positively correlated with nutrient concentration, indicating that the greater the loss, the higher the concentration of the elements in the remaining mass, suggesting immobilization of these nutrients throughout decomposition and $\mathrm{C}$ loss (Schumacher \& Viera, 2015; Singh, Dutta, \& Agrawal, 2004). During litter decomposition, there is an increase in the lignin content, which is a process that occurs throughout the study. In addition, an increase in $\mathrm{N}$ concentration is observed, which plays an important role in lignin degradation (Berg \& McClaugherty, 2008).

The low variation in of $\mathrm{N}$ and $\mathrm{P}$ concentrations in the litter decomposition in $\mathrm{CE}$ can be attributed to low soil fertility and seasonality. Savanna species have ecological strategies for the conservation of functional properties as well as nutrient maintenance and internal cycling, e.g., by nutrient retranslocation followed by leaf dehiscence (Vourlitis et al., 2013), cycling nutrients with minimal losses. 
The higher concentration of $\mathrm{P}$ in the E2 litter probably correlates with the residual effect of fertilization (Table 1) The soil of this area presented about three times more $P$ when compared to the other forests E1 and CE (Table 2), reflecting in a higher concentration of this nutrient in the plant due to the history of use and soil management.

The C:N and C:P ratios had positive correlations with the litter mass loss, due to the $\mathrm{C}$ presenting an average release of $21 \%$ for the three areas over the two-year evaluation. Nutrients and their relationship are complex by the fact that different organisms are involved in the decomposition process, these organisms may acquire nutrients from the abiotic environment in addition to those provided by the litter, and because the rates of decomposition are often limited by the lability of $\mathrm{C}$ compounds rather than by $\mathrm{N}$ or P availability (Gessner \& Chauvet 1994).

Apparently, $\mathrm{N}$ and $\mathrm{P}$ liberation were more efficient in the native vegetation. It is also worth mentioning that if the study period had been only one year (360 days), no difference would have been detectable in the remaining litter mass between Eucalyptus stands and native vegetation. These findings reinforce the importance of long-term studies of native and planted forest ecosystems in the Cerrado.

\section{Acknowledgements}

The study was supported financially by Embrapa Cerrados (Projeto Saltus), University UnB, and Coordenação de Aperfeiçoamento de Pessoal de Nível Superior (CAPES). The authors are indebted to PhD Adilson Jayme-Oliveira, for his help with the laboratory analyses.

\section{References}

Atwell, M. A., Wuddivira, M. N., \& Wilson, M. J. (2018). Sustainable management of tropical small island ecosystems for the optimization of soil natural capital and ecosystem services: A case of a Caribbean soil ecosystem-Aripo savannas Trinidad. Journal of Soils and Sediments, 18(4), 1654-1667. https://doi.org /10.1007/s11368-017-1865-3

Bachega, L. R., Bouillet, J. P., Piccolo, M. C., Saint-André, L., Bouvete, J. M., Nouvellon, Y., ... Laclau, J. P. (2016). Decomposition of Eucalyptus grandis and Acacia mangium leaves and fine roots in tropical conditions did not meet the Home Field Advantage hypothesis. Forest Ecology and Management, 359, 33-43. https://doi.org/10.1016/j.foreco.2015.09.026

Barbosa, V., Barreto-Garcia, P., Gama-Rodrigues, E., \& Paula, A. (2017). Biomassa, carbono e nitrogênio na serapilheira acumulada de florestas plantadas e nativa. Floresta e Ambiente, 24, e20150243. https://doi.org/ 10.1590/2179-8087.024315

Baumann, K., Marschner, P., Smernik, R. J., \& Baldock, J. A. (2009). Residue chemistry and microbial community structure during decomposition of eucalypt, wheat and vetch residues. Soil Biology and Biochemistry, 41(9), 1966-1975. https://doi.org/10.1016/j.soilbio.2009.06.022

Berg, B. (2014). Decomposition patterns for foliar litter - a theory for influencing factors. Soil Biology and Biochemistry, 78, 222-232. https://doi.org/10.1016/j.soilbio.2014.08.005

Berg, B., \& McClaugherty, C. (2008). Plant Litter: Decomposition, Humus Formation, Carbon Sequestration. (2nd ed.). Berlin: Springer. https://doi.org/10.1007/978-3-540-74923-3

Binkley, D., Campoe, O. C., Alvares, C., Carneiro, R. L., Cegatta, I., \& Stape. J. L. (2017). The interactions of climate, spacing and genetics on clonal Eucalyptus plantations across Brazil and Uruguay. Forest Ecology and Management, 405, 271-283. https://doi.org/10.1016/j.foreco.2017.09.050

Brown, M. E., \& Chang, M. C. Y. (2014). Exploring bacterial lignin degradation. Current Opinion of Chemical Biology, 19, 1-7. https://doi.org/10.1016/j.cbpa.2013.11.015

Carvalho, D. C., Pereira, M. G., Toledo, L. O., Simon, C. A., Rodrigues, J. S., Fernandes, J. C. F., \& Silva-Neto, E. C. (2017). Ciclagem de nutrientes de um plantio de eucalipto em regeneração de espécies nativas no sub-bosque. Floresta, 47(1), 17-27. https://doi.org/10.5380/rf.v47i1.43652

Castro, A. P., Silva, M. R. S. S., Quirino, B. F., Bustamante, M. M. C., \& Kruger, R. H. (2016). Microbial Diversity in Cerrado biome (Neotropical Savanna) soils. PloS One, 11(2), e0148785. https://doi.org/ 10.1371/journal.pone. 0148785

Cizungu, L., Staelens, J., Huygens, D., Walangululu, J., Muhindo, D., Cleemput, O. V., \& Boeckx, P. (2014). Litterfall and leaf litter decomposition in a central African tropical mountain forest and Eucalyptus plantation. Forest Ecology and Management, 326, 109-116. https://doi.org/10.1016/j.foreco.2014.04.015 
Claessen, M. E. C. (1997). Manual de métodos de análise de solo (2nd ed.). Rio de Janeiro: Centro Nacional de Pesquisa de Solos.

Conti-Junior, J. L. F., Silva, P. H. M., \& Couto, H. T. Z. (2017). Deposição de folhedo e fluxo de nutrientes em eucalipto geneticamente modificado. Pesquisa Florestal Brasileira, 37(89), 89-92. https://doi.org/10.4336/ 2017.pfb.37.89.985

Corrêa, R. S., Schumacher, M. V., \& Momolli, D. R. (2016). Deposição de serapilheira e micronutrientes ao longo das estações do ano em um plantio de eucalipto estabelecido sobre pastagem natural degradada no bioma Pampa. Scientia Forestalis, 44(110), 435-442. https://doi.org/10.18671/scifor.v44n110.16

Du, H., Zeng, F., Wanxia, P., Wang, K., Zhang, H., Liu, L., \& Song, T. (2015). Carbon storage in a Eucalyptus plantation chronosequence in Southern China. Forests, 6, 1763-1778. https://doi.org/10.1314 0/RG.2.1.4576.0168

Empresa Brasileira de Pesquisa Agropecuária. (2009). Manual de análises químicas de solos, plantas e fertilizantes (2nd ed.). Brasília, DF: Embrapa Informação Tecnológica.

Ferreira, V., Koricheva, J., Pozo, J., \& Graça, M. A. S. (2016). A meta-analysis on the effects of changes in the composition of native forests on litter decomposition in streams. Forest Ecology and Management, 364, 27-38. https://doi.org/10.1016/j.foreco.2016.01.002

Fonseca, E. S., Peixoto, R. S., Rosado, A. S., Balieiro, F. C., Tiedje, J. M., \& Rachid, C. T. C. C. (2018). The microbiome of eucalyptus roots under different management conditions and its potential for biological nitrogen fixation. Microbial Ecology, 75(1), 183-191. https://doi.org/10.1007/s00248-017-1014-y

Freschet, G. T., Cornwell, W. K., Wardle, D. A., Elumeeva, T. G., Liu, W., Jackson, B. G., ... Cornelissen, J. H. C. (2013). Linking litter decomposition of above- and below-ground organs to plant-soil feedbacks worldwide. Journal of Ecology, 101(4), 943-952. https://doi.org/10.1111/1365-2745.12092

Fujii, K., Shibata, M., Kitajima, K., Ichie, T., Kitayama, K., \& Turner, B. L. (2018). Plant-soil interactions maintain biodiversity and functions of tropical forest ecosystems. Ecological Research, 33(1), 149-160. https://doi.org/10.1007/s11284-017-1511-y

Gatto, A., Bussinger, A. P., Ribeiro, F. C., Azevedo, G. B., Bueno, M. C., Monteiro, M. M., \& Souza, PF. (2014). Ciclagem e balanço de nutrientes no sistema solo-planta em um plantio de Eucalyptus sp., no Distrito Federal. Revista Brasileira de Ciência do Solo, 38(3), 879-887. https://doi.org/10.1590/S0100-068320 14000300019

Gessner, M. O., \& Chauvet, E. (1994). Importance of stream microfungi in controlling breakdown rates of leaf litter. Ecology, 75(6), 1807-1817. https://doi.org/10.2307/1939639

Giácomo, R. G., Pereira, M. G., \& Machado, D. L. (2012). Aporte e decomposição de serapilheira em áreas de Cerradão e Mata Mesofítica na Estação Ecológica de Pirapitinga-MG. Ciência Florestal, 22(4), 669-680. https://doi.org/10.5902/198050987549

Guendehou, G. H., Liski, J., Tuomi, M., Moudachirou, M., Sinsin, B., \& Mäkipää, R. (2014). Decomposition and changes in chemical composition of leaf litter of five dominant tree species in a West African tropical forest. Tropical Ecology, 55(2), 207-220.

Hakamada, R., Hubbard, R. M., Ferraz, S., Stape, J. L., \& Lemos. C. (2017). Biomass production and potential water stress increase with planting density in four highly productive clonal Eucalyptus genotypes. Southern Forests, 79(3), 251-257. https://doi.org/10.2989/20702620.2016.1256041

Hammel, K. E. (1997). Fungal degradation of lignin. In G. Cadish, \& K. E. Giller (Eds.), Driven by Nature: Plant litter quality and decomposition (pp. 33-46). Walingford, CAB International: Madison, USA.

He, H., Song, Q. M., Wang, Y. F., \& Yu, S. X. (2014). Phytotoxic effects of volatile organic compounds in soil water taken from a Eucalyptus urophylla plantation. Plant and Soil, 377(1-2), 203-215. https://doi.org/10.10 07/s11104-013-1989-1

Hobbie, S. E. (2015). Plant species effects on nutrient cycling: Revisiting litter feedbacks. Trends in Ecology and Evolution, 30(6), 357-36. https://doi.org/10.1016/j.tree.2015.03.015

Intergovernmental Panel on Climate Change. (2007). Climate Change. The Physical Science Basis. Contribution of Working Group I to the Fourth Assessment Report of the Intergovernmental Panel on Climate Change. Cambridge, UK. 
León, J. D., \& Osorio, N. W. (2014). Role of litter turnover in soil quality in tropical degraded lands of Colombia. The Scientific World Journal, 2014, 693981. http://doi.org/10.1155/2014/693981

Nouvellon, Y. P., Epron, D., Marsden, C., Kinana, A., Maire, G., Deleporte, P., ... Laclau, J. P. (2012). Age-related changes in litter inputs explain annual trends in soil $\mathrm{CO}_{2}$ effluxes over a full Eucalyptus rotation after afforestation of a tropical savannah. Biogeochemistry, 111(1-3), 515-533. https://doi.org/10.1007/s10533011-9685-9

Oliveira, B., Marimon-Junior, B. H., Mews, H. A., Valadão, M. B. X., \& Marimon, B. S. (2017). Unraveling the ecosystem functions in the Amazonia-Cerrado transition: evidence of hyperdynamic nutrient cycling. Plant Ecology, 218(2), 225-239. https://doi.org/10.1007/s11258-016-0681-y

Oliveira, W. R. D., Ramos, M. L. G., Carvalho, A. M., Coser, T. R., Silva, A. M. M., Lacerda, M. M., ... Pulrolnik, K. (2016). Dynamics of soil microbiological attributes under integrated production systems, continuous pasture, and native cerrado. Pesquisa Agropecuária Brasileira, 51(9), 1501-1510. https://doi.org/10.1590/ s0100-204x2016000900049

Olson, J. S. (1963). Energy storage and the balance of producers and decomposers in ecological systems. Ecology, 44(2), 322-331. https://doi.org/10.2307/1932179

Osborne, B. B., Nasto, M. K., Asner, G. P., Balzotti, C. S., Cleveland, C. C., Sullivan, B. W., \& Porder, S. (2017). Climate, topography, and canopy chemistry exert hierarchical control over soil $\mathrm{N}$ cycling in a Neotropical Lowland Forest. Ecosytems, 20(6), 1089-1103. https://doi.org/10.1007/s10021-016-0095-7

Paiva, H. N., \& Leite, H. G. (2015). Desbastes e desramas em povoamentos de Eucalyptus. In M. V. Schumacher \& M. Viera (Eds.), Silvicultura do eucalipto no Brasil (pp. 83-112). Santa Maria: Editora UFSM.

Pinto, H. C. A., Barreto, P. A. B., Gama-Rodrigues, E. F., Oliveira, F. G. R. B., Paula, A., \& Amaral, A. R. (2016). Decomposição da serapilheira foliar de floresta nativa e plantios de Pterogyne nitens e Eucalyptus urophylla no sudoeste da Bahia. Ciência Florestal, 26(4), 1141-1153. https://doi.org/10.5902/198050 9825105

Prescott, C. E., \& Grayston, S. J. (2013). Tree species influence on microbial communities in litter and soil: Current knowledge and research needs. Forest Ecology and Management, 309, 19-27. https://doi.org/10.10 16/j.foreco.2013.02.034

Ribeiro, F. P., Bussinguer, A. P., Hodecker, B. E. R., \& Gatto, A. (2017). Conteúdo de nutrientes na serapilheira em três fisionomias do Cerrado do Distrito Federal. Pesquisa Florestal Brasileira, 37(39), 465-473. https://doi.org/10.4336/2017.pfb.37.92.1312

Robertson, J. B., \& Van Soest, P. J. (1981). The detergent system of analysis and its application to human foods. In W. P. T. James, \& O. Theander (Eds.), The analysis of dietary fiber in food (pp. 123-158). New York: Marcel Dekker.

Santos, A. F. A., Carneiro, A. C. P., Martinez, D. T., \& Caldeira, S. F. (2017). Capacidade de retenção hídrica do estoque de serapilheira de eucalipto. Floresta e Ambiente, 24, e20150303. https://doi.org/10.1590/2179-80 87.030315

Santos, H. G., Jacomine, P. K. T., Anjos, L. H. C., Oliveira, V. A., Oliveira, J. B., Coelho, M. R., ... Cunha, T. J. F. (2013). Sistema brasileiro de classificação de solos (3rd ed.). Rio de Janeiro: Embrapa Solos.

Santos, P. F., \& Whitford, W. G. (1981). The effects of microarthropods on litter decomposition in a Chihuazhuan ecosystem. Ecology, 62(3), 654-663. https://doi.org/10.2307/1937733

Schumacher, M. V., Corrêa, R. S., Viera, M., \& Araújo, E. F. (2013). Produção e decomposição de serapilheira em um povoamento de Eucalyptus urophylla $\times$ Eucalyptus globulus Maidenii. Cerne, 19, 501-508. https://doi.org/10.1590/S0104-77602013000300018

Schumacher, M. V., \& Viera, M. (2015). Silvicultura do eucalipto no Brasil. In M. V. Schumacher, \& M. Viera (Eds.). Ciclagem de nutrientes em plantações de eucalipto (pp. 273-307). Santa Maria: Editora UFSM.

Silva, L. V. B., \& Vasconcelos, H. L. (2011). Plant palatability to leaf-cutter ants (Atta laevigata) and litter decomposability in a Neotropical woodland savanna. Austral Ecology, 36(5), 504-510. https://doi.org/ 10.1111/j.1442-9993.2010.02169.x

Singh, R. K., Dutta, R. K., \& Agrawal, M. (2004). Litter decomposition and nutrient release in relation to atmospheric deposition of $\mathrm{S}$ and $\mathrm{N}$ in tropical region. Pedobiologia, 48(4), 305-311. https://doi.org/ 10.1016/j.pedobi.2004.03.003 
Souza, J. V., Ribeiro, F. C., Bussinguer, A. P., Hodecker, B. E. R., Valadão, M. B. X., \& Gatto A. (2016). Stock and litter decomposition in different vegetation types and eucalypt plantations in the cerrado region, Brazil. Australian Journal of Basic and Apllied Sciences, 10(18), 74-81.

Swift, M. J., Heal, O. W., \& Anderson, J. M. (1979). The influence of resource quality on decomposition processes. In D. J. Anderson, P. Greig-Smith, \& F. A. Pitelka (Eds.), Decomposition in terrestrial ecosystems (pp. 118-166). Berkeley, CA: University of California Press.

Turner, J., \& Lambert, M. (2016). Pattern of carbon and nutrient cycling in a small Eucalyptus forest catchment, NSW. Forest Ecology and Management, 372, 258-268. https://doi.org/10.1016/j.foreco.2016.04.012

Viera, M., Schumacher, M. V., \& Araújo, E. F. (2014). Disponibilização de nutrientes via decomposição da serapilheira foliar em um plantio de Eucalyptus urophylla $\times$ Eucalyptus globulus. Floresta e Ambiente, 21(3), 307-315. https://dx.doi.org/10.1590/2179-8087.066313

Vitousek, P. M., \& Sanford Jr., R. L. (1986). Nutrient cycling in moist tropical forest. Annual Review of Ecology and Systematics, 17, 137-167.

Vourlitis, G. L., Lobo, F. A., Lawrence, S., Lucena, I. C., Borges, O. P., Dalmagro, H. J., .. Nogueira, J. S. (2013). Variations in stand structure and diversity along a soil fertility gradient in a Brazilian savanna (Cerrado) in southern Mato Grosso. Soil Science Society of American Journal, 77(4), 1370-1379. https://doi.org/10.2136/ sssaj20 12.0336

Wagner, G. H., \& Wolf, D. C. (1999). Carbon transformations and soil organic matter formation. In D. M. Sylvia, J. J. Fuhrmann, P. G. Hartel, \& D. A. Zuberer (Eds.). Principles and applications of soil microbiology (pp. 218-256). New Jersey: Prentice Hall.

Wink, C., Reinert, D. J., Müller, I., Reichert, J. M., \& Jacomet, L. (2013). A idade das plantações de Eucalyptus sp. influenciando os estoques de carbono. Ciência Florestal, 23(2), 333-343. https://doi.org/10.5902/19805 0989279

Zanetti, R., Zanuncio, J. C., Santos, J. C., Silva, W. L. P., Ribeiro, G. T., \& Lemes, P. G. (2014). An overview of integrated management of leaf-cutting ants (Hymenoptera: Formicidae) in Brazilian forest plantations. Forests, 5(3), 439-454. https://doi.org/10.3390/f5030439

Zhang, H., Yuan, W., Dong, W., \& Liu, S. (2014). Seasonal patterns of litterfall in forest ecosystem worldwide. Ecological Complexity, 20, 240-247. https://doi.org/10.1016/j.ecocom.2014.01.003

\section{Copyrights}

Copyright for this article is retained by the author(s), with first publication rights granted to the journal.

This is an open-access article distributed under the terms and conditions of the Creative Commons Attribution license (http://creativecommons.org/licenses/by/4.0/). 